\section{Physical disability, rehabilitation, and health promotion: a case study in Brazil}

\author{
Deficiência física, reabilitação e promoção da \\ saúde: um estudo de caso no Brasil
} Discapacidad física, rehabilitación y promoción
de la salud: un estudio de caso en Brasil
Marcelo Simões Mendes 1,2

Juan Carlos Aneiros Fernandez 2

doi: 10.1590/0102-311X00056520

\begin{abstract}
Reflecting on the health promotion for people with physical impairments implies considering the specificities and meanings attributed to the life experience of each subject throughout their careers. As such, this study was designed to investigate the experience of a man with an acquired physical disability

Correspondence

M. S. Mendes

R. Ari Barroso 173, Paulinia, SP 13141-075, Brasil.

m_smendes@outlook.com

${ }^{1}$ Association for Psychological Science, Washington DC, U.S.A.

2 Universidade Estadual de Campinas, Campinas, Brasil.
\end{abstract} after an accident that damaged his spine. This injury caused a permanent inability to move his legs. It is a case study that used the life history technique to capture its experience. The participant was born in a rural context, and since he was a child, he had to work to help his family. At the age of 16, he started working as a chainsaw operator, and at 24, a tree fell on his back, breaking his spine and leaving him without the movements and sensitivities of his legs. The trauma experienced by the participant caused profound changes in his life. The results demonstrated that the participant's experience does not align with the traditional experiences found in the literature in general, as the concept of biographical rupture. Sport was a vital collaboration mechanism in the rehabilitation process. Concerning health and illness, there are many spaces in the subject's experience that collaborate to expand the compression on health promotion paths. The need to depathologize the gaze on the subject's conditions is highlighted so that the understanding of health promotion processes can be amplified or reconsidered.

Disabled Persons; Life Change Events; Health Promotion; Qualitative Research 


\section{Introduction}

In Brazil, the theme of physical disability reveals a recent academic-scientific interest. A study by Mendes \& Canesqui 1 searched the Scientific Electronic Library Online (SciELO) for academic articles based on the keyword "physical disability". It founded only 18 articles. In an expanded search carried out in SciELO based on the keywords "physical disability" and "disability", 167 studies were found, and $92.3 \%$ of these publications occurred between 2005 and 20142.

Although such production is recent, the phenomenon of physical disability is old, and conceptions and representations about the body throughout history exemplify the multiplicity of meanings given to this issue. In Ancient Greece, Plato asserted that education should give the body and soul every possible perfection ${ }^{3}$.

The Greek civilization is not only an example, but also a benchmark on how the conjecture of beautiful-ugly, beauteous-shapeless cross the human experience by the figure and symbol of the body. According to Ortega 4 , dietetics in the Greek ascetic process were subordinated to the general principle of the aesthetics of existence, and those dietetics assumed a reflective practice of oneself. One's body becomes a fundamental component of political life that is not only biopolitics but rather freedom of action.

Concerning the physically impaired body, in 19th-century Europe, there were several "shows" that featured children and adults with such impairments, many of them organized by their parents. From "elephant man" to "phenomenon boys" (two children with the same body), public squares and circuses were the made scenes of these people. Deformities, illnesses, and mutilations became the first forms of the modern mass entertainment industry ${ }^{5}$. Such bodily "anomalies" bestowed monstrosities, and thus, according to Courtine 5, the "elephant man", the "camel woman", "the armless child", the "black-white" are no longer seen according to their gender, age, illness or ethnicity.

In the contemporary world, people with physical disabilities are more protected by law but still exposed to different gazes. The experiences of a person with physical disabilities, in various contexts, have been mainly marked by embarrassing situations: stigma 6 , discrimination 7 , and even exposure to violence 8 .

The capture of the subject's experience is no simple task and must involve the development of many aspects of this process. From the concept's perspective, there is a substantial difference between physical disabilities and physical impairments. The conceptual distinction both terms is notably significant to comprehension of the experience of the participant of this study.

Physical disability comprises a classical categorization regarding biophysical consequences from some detectable body disorder (traumas, accidents, diseases, etc.). This concept tends to insert the human experience on generality and demonstrates vigorous support from the biomedical paradigm. As for the concept of physical impairments, there is an a qualitative principle to comprehend the singular experience considering the profound interference of social aspects in which, according to the social model 9 , might produce physical disabilities. For example, one might easily observe differences on the experience of a person with a spine lesion compared to a person with a transient foot injury.

From the participant's experience of this study it is possible to note and distinguish characteristics of both concepts. The participant was born in a rural context, and since he was a child, he had to work to help his family. Autonomy to solve practical problems was common in his daily life. Freedom is another value that composed his life before the injury, and both these characteristics are crucial to consider distinguishing physical disabilities from physical impairments.

\section{Purpose}

This study aimed to investigate the experience of the person with physical impairments, seeking to conduct a critical discussion about the health promotion processes for this subject. 


\section{Methods}

\section{Instruments}

The primary purpose of this study was to understand the subject's experience in depth. A case study made using the life history technique to capture multiple aspects that correspond to the subject's experience with acquired physical impairments. Semi-structured interviews conducted in which a triggering question started the data collection and analysis process. Such a question was: "Could you tell me your life story?”.

\section{Case study}

According to Yin 10, the case study is used to understand individual, group, organizational, social, and political phenomena, contributing to the understanding of the complexity surrounding these phenomena. In short, the case study method enables researchers to retain meaningful and holistic features of real-life events, such as individual life cycles 10.

This study focused on the subject's experience with acquired physical disabilities and, after his accident, sought to practice sports to promote his health and as a mechanism of socialization.

\section{Life history}

Life history is a technique that allows a qualitative analysis of the life trajectories narrated by its protagonists, which aims to value and add to the fact or phenomenon the set of elements that give them their complexity, completeness, and legitimacy 11. It seeks silences, "the unspoken," definitive or repressed forgetting 12, discontinuities, gestures, and idiosyncrasies 13 , affections, values, and ideologies 14 , which the subject uses to construct and give meaning to his memory, the raw material for the interpretative work by the researcher.

\section{Procedures}

After approval by the Ethics Research Committee by University of Campinas (CAAE 30338714.6.0000.5404), the process of approximation with the field started. Given that the central axis of this study comprises the field of health promotion and its interfaces with sport and physical activity, the authors identified an institution that developed activities in this regard.

Initially, it predicted only one interview. However, due to the necessity to comprehend this case in depth, two additional interviews were conducted. The first interview lasted approximately 50 minutes. The other two lasted around 90 minutes. All interviews were conducted at the participant's house.

\section{Data analysis}

The process of interpretation and understanding of the material collected in this present study takes as reference the sociological phenomenology of Schutz 15. For the understanding of social reality, we start from a "natural attitude", for which the world is, from the outset, not the private world of the individual, but an intersubjective world in which we do not have a theoretical interest but an eminently practical interest. The world of everyday life is the scene as well as the object of our actions and interactions 15 .

On the scientific method's interpretation of the "natural attitude", Schutz 15 states that the "world of everyday life" implies a determined biographical situation that positions the subject at all times of his life. This situation denotes an environment that goes beyond the physical dimension and comprises social, cultural, moral, and ideological aspects.

Every moment of a person's life is the determining biographical situation in which they find themselves, that is, the physical and socio-cultural environment defined by oneself, within which one has 
its position, not just position in terms of physical space and time. Alternatively, it is status and role within the social system and his/her moral and ideological position 15.

Schutz's proposal to understand the subject's experience aligns with the principles sought in this research to produce knowledge. In other words, the authors value the indeterminate, the "inconsistencies", the return to the same things as they are produced by those who produce them, trying to detach themselves from the gaze that observes the "scientific" bases that do not allow what is to be really seen.

\section{Results}

\section{A brief note about the participant}

The participant received the fictitious name of Apollo and, at the time of the interviews in 2015, was 41 years old. He was born in a rural context and lived in a city in Roraima State (northern Brazil) until his accident. Apollo had to work to help his family, and he had been highly active since childhood. At the age of seven, he was already milking cows and delivering the product to the city by bicycle.

At the age of 16, he started working as a chainsaw operator, and at 24, a tree fell on his back, breaking his spine and leaving him without the movements and sensitivities of his legs. With no resources for treatment, he moved to his sister's house in a city in the state of São Paulo, Brazil, where he managed to have surgery to stabilize his spine erectly.

Apollo said he did not seek help or information about how to do with daily procedures (cleaning, walking, and others) in the rehabilitation process. He claimed that his "rehab was practice". In 2011, he started some sporting practices that have played a significant role in his life. All the participant's narratives were literally translated by the authors trying to preserve the maximum of their originality. For this reason, there are many spelling and grammatical errors in his piece.

\section{The depathologization of understanding}

When asked for Apollo to report on his life story, the authors faced with a triple sense about the importance that sport assumed in his life: a mechanism of defense of the subject to self-affirm his abilities; a reflexive and inadvertent attitude of the researcher in considering the informant weakened; and the description 16 of things as they are expressed in their own way, which we develop in a section later.

Said Apollo: "So I have been a paraplegic for 17 years and had an accident and such, and I became paraplegic, and after a while, I started working and then I started practicing a sport. I got into the sport, and I was (...) I went to play handball in 2011. And as soon as I started training, I went to play in a Brazilian championship, and I managed to be first in the Brazilian, and it was good. Then it was just experience of more training, training and then we have already conquered the Paulista championship, I have completed a South American and now I competed, I started going to athletics, and I started training, and I was already competing for the regional ones. We got some medals too, and I have already competed for two regionals and already got one gold and one bronze and silver in the others too. I had a boxing circuit right, and we got bronze, right. It is hard there, but...".

Initially, the authors understood the symbolism by the sports as a way not to return to painful events of his trajectory and function as an instrument that helps the subject reassert himself as a capable subject with many potentialities. This interpretation considers many symbols that mean these characteristics of its practitioners in the social and cultural imagination.

According to Goffman ${ }^{17}$, societies, through their social values, instituted throughout history, establish ways to classify and characterize people and their qualities. This characterization also permeates the athlete's representations, causing the athlete to carry in his image values of high capacity, dexterity, and abilities.

When the interview started, the researchers perceived that direction towards the achievements that Apollo obtained in the sport even worked as a defense mechanism against the image to be passed to the researcher. That moment was the first contact between them.

In the second, the "defense" perceived by the researcher at the beginning of the first contact understood as the expected self-defense of meeting someone for the first time. and not a defense for feeling 
inferior due to being in a wheelchair, which in this case it would be more linked to the gaze of the researcher than to that of Apollo himself.

This consideration allows reflecting on an essential issue for health promotion: the depathologization of understandings. To think that stigmatizing preconceptions may come not from the subject, but from who perceives and relates to it. After all, a subject may have an injury but not undergo the disability experience 18 .

This discussion leads the researchers and other health professionals to consider something central in the field of disability, that reflects directly on the process of health promotion: more parameters are needed to define disability than an injury to L1 or to have a disability.

Does failure to perform the tasks of "normal" daily life 6 can define whether the subject feels disabled? Being a person with disabilities implies the complexity between how subjects perceive themselves and how society defines them, oppresses them, and creates social barriers to their participation, according to the social model ${ }^{19}$. Thus, the injury would be a biological phenomenon and disability a social phenomenon 20.

Models that deal directly with conceptions of disability that directly affect the types of treatment and health promotion are often polarized. On the one hand, the biological dimension 21 of what it means to be a person with disabilities and on the other socially and culturally constructed disability 19 .

The International Classification of Functioning 22 contributed to a more integrated perspective from a proposal to join the biomedical and social models 23 through a biopsychosocial conception of the subject. However, even with this advance, the subject seems to be understood in a compartmentalized, fractional, and thus reduced manner.

This reduction may affect the subject, which is then considered hyposufficient, as pointed out by Fernandez 24. The fixation of identity from the perspective of a disabling condition corroborates a unique classification of both their possibilities and their disabilities.

Thus, the reduction of the subject and its experience through this fractionation is supported by rationalities that do not only locate in the health field but the social imaginary of Western societies. Small space exists for the unpredictable 25 , complex 26 experience, since the social order is not developed to accept ambivalence 27 .

\section{Is there a subject between health and disease?}

The difficulties of considering the subject's experience beyond the prevailing rationalities determined are a reality in health promotion. Medical protocols prescribe guidelines on the procedures developed. Despite the crucial importance of these protocols, it is necessary to consider that these guidelines and procedures will present intersections with meanings and values where the subject's experience is constructed.

Thus, the discussion intended to promote is not to judge biomedical care to the point of reducing it to mere procedures. As indicated, these are often necessary procedures for the maintenance and survival of biological health, since being bodily is an existential condition of human life, as indicated by Merleau-Ponty 28. The dialogue that is sought is in another dimension, where bifocal lenses often cannot see since they can see either what is far or near and never both distances at the same time.

There is little space for physically impaired subjects to assume their injury without experiencing its impediments. The foundations of the conceptions that allow the complexity of being or not being a disabled person (with or without injury) are fragile to support the existence of the subject with physical impairments.

Many conceptions still move actively in the social imagination, including those that attest to physical disability as a disease. This latter conception provides material on the difficult task of indicating the boundaries between health and disease.

The discussion sought is not to establish the boundaries for the binomial health/disease, but to show that these boundaries cannot divide a space that can be the same among so many boundaries that constitute it.

Finally, attesting to physical disability as a disease may favor the construction of protocols and measures to be taken given the situation presented by the subject, especially from the perspective of biomedical thinking for health promotion. However, a thoughtful dialogue between limitations and 
abilities should be assumed so that the health of this subject does not risk "getting sick" due to the classification received.

Regarding these statements that involve health and disease considerations, Canguilhem 29 and Scliar 30,31 presented historical parameters that help to understand the influences that the conception of health and disease presented over time. These parameters contribute to explain, in some instances, our current models of treatment and health promotion.

The historical parameters of health construction present the influences under which health care and treatment based on developing their investigative methods and intervention protocols. The pathogenic paradigm seems to have exerted a strong influence on the construction of such procedures, often limiting the understanding of the subject's impediments.

From the perspective of the pathogenic paradigm, a reduction operates from the need to classify the subject as a person with or without physical disabilities. In turn, this taxonomy comprises a reduced understanding of the subject with such impediments.

By way of example, for some people who could perform activities of daily living (ADLs), it meant not being a person with disabilities, and for others who could perform ADLs, but could no longer perform their work activities, meant being a person with impairments 6 . What is the subject's life experience that allows us to consider health and illness in the subject's experience with physical impairments? The question itself seems to be wrongly formulated, since it is not a dimension, but a dynamic set of factors associated with other factors that intersect, and often overlap each other.

In this interposition and overlap of factors associated with the subject's health and illness, there is a need to recognize the place or legitimacy of inconsistency, ambivalence and the unpredictable in the subject's experience, since for Arendt 25 such unpredictability may mean a potent source of restart and reconfiguration of the human scenario. This reconfiguration of the human condition brings innumerable ways of understanding the subject's health and disease states, no longer under a static and simplistic look at both conditions, but with a unique dynamism that makes them - health and disease - human conditions. And, therefore, complex and comprehensive.

\section{Injury emergence: disrupting the notion of biographic rupture}

Although the accident is a harrowing episode and has consequences in many spheres, permanent trauma experience does not need or cannot be considered only from the perspective of lamentation and victimization. The position presented by Apollo differs from victimization because as much as the injury may have impacted him, he re-signified his existence by further valuing his life purposes.

Under the focus of existential phenomenology 28, Pompeia \& Sapienza 32 point out that body transformation arising from amputations, paraplegia, tetraplegia, or other dysfunctions, evoke interpretations of the subject that penetrate the world of their meanings, thus causing transformations of all kinds.

Concerning the changes that a chronic disease causes in a person's life, Bury 33 states that this type of disease is the most exceptional type of biographical rupture experience. On the biographical rupture experience, it is crucial to distinguish impairments from the disease. Impairments cannot totalize as a cause of the development of diseases and vice-versa. In this way, these conditions occupy different attributes on the subject's health promotion, and they cannot be understanding as equivalent in meaning.

Apollo's experience denotes a position that breaks with representations of victimization according to which a subject puts himself in a passive condition alienated from his possibilities for transformation. During the interview, Apollo was more troubled when talking about his ex-wife, who had left him, than when mentioning the accident itself.

The idea is not to trivialize the difficulties the person faces with physical impediments, but to recognize the meanings given by the subject to all dimensions that make up their daily life; to value his proactivity for a profound, lasting transformation that reflects on his health condition. As Apollo said: "I live better today than before".

In this way, Apollo's experience reveals a "rupture" with a rigid idea of biographical rupture, since biographical ruptures should not only be understood as processes of loss and gain but as possibilities for the profound reinvention of one's biography altogether. 
Thus, the biographical rupture needs to understand beyond what is left behind and less to come, because otherwise there is a risk of situating health and disease only from the perspective of causality and not in what makes it possible. Perhaps in the present experience, constructed and reconstructed by the resignification of the senses of the rupture and not strictly in the accumulation of the experiences, more authentic possibilities of the construction of a healthier experience can fit.

\section{Rehabilitation: implications of the phenomenal body}

Apollo showed an intense commitment to overcome barriers and adapt to his new life structure.

"I will have to learn to do it all over again. And always, like this, I have been a person who learned how to do my things like that daily, always learned by myself, right? Today I live alone, I have lived alone again before. I even lived of favors in my sister's house. I always took care of myself, and I always took care of myself. So I have never been this way to tease anyone. Since I have got this kind of disability, I'll get over it. Learning everything by myself, I did not go to these rehab things at all. My rehabilitation was daily" (Apollo).

The need for readjustment to the new ways of life of the disabled person implies dealing with the body and corporeality. Merleau-Ponty 28 states that understanding the perception of the world and the positioning of the subject in the construction of his corporeality-subjectivity implies, a priori, to admit existence as a bodily experience.

In this relationship, the philosopher highlights the importance of the body in perception and intervention in the world by differentiating two ways of conceiving it: the objective body and the phenomenal body. The objective body is the object body of the world, whose meaning aggregates representations that presuppose an external and distant gaze from the body. In other words, the idea of the body and its meanings. On the other hand, the phenomenal body is where the current experience lived and the truth of the experience of being 34 .

Apollo's experience in dealing with the changes in his life (and therefore, his body) reveals much closer evidence of the phenomenal body. This situation is justified by the ownership in which Apollo dealt and deals with the changes arising from his adaptation.

As reported by the participant, he always had the initiative to perform the tasks for himself and that his rehabilitation was "day by day". This position in the face of adversity and the need for change problematizes part of Goffman's considerations ${ }^{17}$, reporting that a predisposition to victimization could reveal stigmatized responses to situations.

The bodily experience is presented by both the objective body and the phenomenal body, not by a dichotomous union, but by reciprocity. The objective body reveals the representations of the subject's experience, which could not be constructed if not for the properties of the phenomenal body. What may be the differential for distinguishing bodily and, thus, existential experiences is how much and how subjects use this reciprocal relationship to construct their experience.

Investing in the objective body implies being linked to social and collective representations since, in this body are the ideological, cultural, and value-based impressions filtered by the subject's experience. As for the phenomenal body, there are the characteristics of the objective body, but in this case, under the possession of position on the directions of this objective body.

Furthermore, in this statement of the phenomenal body, they lay the foundations for psychological empowerment since it denotes, by the subject, a feeling of greater control over one's life 35,36 . Thus, the existential experience strengthened by an authentic and autonomous body experience, within human limitations, can have lasting elements for the health promotion of the subject.

From the perspective of a reductive understanding, autonomy stands for health as limitation stands for the disease. Some studies present actions for the inclusion and development of autonomy in the work context ${ }^{37}$, of education 38 , and health 39 .

The implements towards the development of accessibility, inclusion policies, and biomedical health care have significantly contributed to a more autonomous and participative experience. However, there seems to be a universe of possibilities beyond the traditional representations of autonomy hidden in the experience of the physically impaired person. On the other hand, there are far more implications for the person's limitations with their impairments than the lack of proper inclination of a hospital ramp. 
Autonomy and limitations seem to circumscribe in an objective body whose ideologies are limited in their comprehension. However, the most aggravating factor is when autonomy and limitation find representations in the phenomenal body in a consolidated and static way.

The body with impairments denotes representations of the objective body built throughout history and which, in this perspective, present the materiality of judgments, prejudices, and stigma. To deal with these representations is no easy task. It requires a very present phenomenal body and with solid foundations. In this sense, the sport seems to have offered several aids so that Apollo could consolidate the foundations of his phenomenal body and thus act more appropriately in and with his objective body.

\section{Conclusions}

Hyposufficiency may have a twofold aspect, or rather, it may be situated at the two poles that involve health promotion: the subject under care and the caregiver. The difficulties and limitations that involve various health work conditions can lead to dangerous situations, often "hidden" from the health promotion discourse: how much such conditions can contribute to a hyposufficient condition not because the patient is in this condition but by the very alienating definition of health workers who understand it in this way. In this discourse, the worker himself is hyposufficient not in his role as a "health transformer", but as a social transformer. This position is significantly dangerous because it feeds a system alienating from the impossibilities of social transformation, resulting from the possibilities of transformation into health.

Apollo has demonstrated singularities throughout his life's history that implies the necessity to consider the health promotion of people with physical disabilities, not in general terms. The autonomy and freedom lived by Apollo in his childhood seem to have profound implications the way he faced the challenges of his life.

Due to the disruption of the fixation of the subject's hyposufficient conditions, often attributed by the view of the subjects who "take care of it", the possibilities of undergoing an experience in these conditions of rupture contribute to the development of a feeling of greater control in the subject's life and higher belonging to different social groups, which are fundamental characteristics of psychological empowerment 35,36. Directly associated with the field of health promotion, these characteristics may reflect on the strengthening of the subject's self-esteem, on their ability to adapt and on the development of self-help and solidarity, making sport a significant protective factor 40 .

\section{Contributors}

M. S. Mendes and J. C. A. Fernandez participated in the conception, design, analysis, interpretation of data, review and approval of the final version of the article.

\section{Additional informations}

ORCID: Marcelo Simões Mendes (0000-00023932-3240); Juan Carlos Aneiros Fernandez (00000001-8598-646X). 


\section{References}

1. Mendes MS, Canesqui AM. Physical disability: review and considerations. Rev Ciênc Méd (Campinas) 2015; 24:63-73.

2. Mendes MS. Deficiência física e promoção da saúde: o lugar do sujeito [Master's Thesis]. Campinas: Universidade Estadual de Campinas; 2016.

3. Plato. The apology. Scotts Valey: CreateSpace; 2011.

4. Ortega F. O corpo incerto: corporeidade, tecnologias médicas e cultura contemporânea. Rio de Janeiro: Garamond; 2008.

5. Courtine JJ. O corpo anormal: história e antropologia culturais da deformidade. In: Corbin A, Courtine JJ, Viegarello G, organizadores. A história do corpo: as mutações do olhar no século XX. Petrópolis: Editora Vozes; 2008. p. 253-340.

6. Martins JA, Barsaglini RA. Aspects of identity in the experience of physical disabilities: a social-anthropological view. Interface (Botucatu) 2011; 15:109-21.

7. Dovidio JF, Pagotto L, Hebl MR. Implicit attitudes and discrimination against people with physical disabilities. In: Wiener R, Willborn S, editors. Disability and aging discrimination. New York: Springer; 2011. p. 157-83.

8. Cavalcante FG, Minayo MCS. Social representations of rights and violence in the disability field. Ciênc Saúde Colet 2009; 14:57-66.

9. Hughes B, Paterson K. The social model of disability and the disappearing body: towards a sociology of impairment. Disabil Soc 1997; 12:325-40.

10. Yin RK. Applications of case study research. 3rd Ed. Thousand Oaks: SAGE; 2012.

11. Rubio K. O atleta e o mito do herói: o imaginário esportivo contemporâneo. São Paulo: Casa do Psicólogo; 2001.

12. Pollack M. Memória, esquecimento, silencio. Estudos Históricos 1989; 2:3-15.

13. Meihy JCSB, Holanda F. História oral: como fazer, como pensar. São Paulo: Contexto; 2007.

14. Bosi E. Memória e sociedade: lembranças de velhos. 3rd Ed. São Paulo: Companhia das Letras; 1994.

15. Schutz A. Fenomenologia e relações sociais. Rio de Janeiro: Zahar Editores; 1979.

16. Maffesoli, M. Elogio da razão sensível. Petrópolis: Editora Vozes; 1998.

17. Goffman E. Stigma: notes on the manipulation of spoiled identity. Englewood Cliffs: Prentice-Hall; 1963.

18. Piccolo GM, Mendes EG. Contributions to a sociological thinking about disability. Educ Soc 2013; 34:459-75.

19. Diniz D, Barbosa L, Santos WR. Disability, human rights and justice. Sur Rev Int Direitos Human (Impr) 2009; 6:65-77.

20. Bampi LNS, Guilhem D, Alves ED. Social model: a new approach of the disability theme. Rev Latinoam Enferm 2010; 18:816-23.
21. World Health Organization. International classification of impairments, disabilities, and handcaps. Geneva: World Health Organization; 1980.

22. World Health Organization. International classification of functioning, disability and health. Geneva: World Health Organization; 2001.

23. Sampaio RF, Luz MT. Funcionalidade e incapacidade humana: explorando o escopo da classificação internacional da Organização Mundial da Saúde. Cad Saúde Pública 2009; 25:475-83.

24. Fernandez JCA. Promoção da saúde e dinâmica social: o lugar dos sujeitos [Master's Thesis]. Sao Paulo: Universidade de São Paulo; 2011.

25. Arendt H. The human condition. 2nd Ed. Chicago: University of Chicago Press; 1998.

26. Morin E. Ciência com consciência. 14th Ed. Rio de Janeiro: Bertrand Brasil; 2010.

27. Bauman Z. Modernity and ambivalence. Cambridge: Polity Press; 1993.

28. Merleau-Ponty M. Fenomenologia da percepção. 4th Ed. São Paulo: Martins Fontes; 2011.

29. Canguilhem G. O normal e o patológico. 7th Ed. Rio de Janeiro: Forense Universitária; 2011.

30. Scliar M. Do mágico ao social: trajetória da saúde pública. 2nd Ed. São Paulo: Editora SENAC São Paulo; 2005.

31. Scliar M. History of the concept of health. Physis (Rio J.) 2007; 17:29-41.

32. Pompeia JA, Sapienza BT. Os dois nascimentos do homem: escritos sobre terapia e educação na era da técnica. Rio de Janeiro: Via Verita; 2011.

33. Bury M. Chronic illness as biographical disruption. Sociol Health Illn 1982; 4:167-82.

34. Betti M, Kunz E, Araújo LCG, Gomes-da-Silva E. Towards a didactic of possibility: implications of Merleau-Ponty's phenomenology for physical education. Rev Bras Ciênc Esporte 2007; 28:39-53.

35. Carvalho SR. Health promotion contradictions regarding the issues of the subject and the social change. Ciênc Saúde Colet 2004; 9:669-78.

36. Carvalho SR. Os múltiplos sentidos da categoria "empowerment" no projeto de Promoção à Saúde. Cad Saúde Pública 2004; 20:1088-95.

37. Lima MP, Tavares NV, Brito MJ, Cappelle MAC. The meaning of work for persons with disability. RAM. Revista de Administração Mackenzie 2013; 14:42-68.

38. Reganhan WG, Braccialli LMP. Inclusion of students with disabilities in regular school: profile of the city of Marília. Rev Bras Educ Espec 2008; 14:385-404.

39. Leite VBE, Faro ACM. The care of the nurse specialized in physical-motor rehabilitation. Rev Esc Enferm USP 2005; 39:92-6.

40. Poletto M, Koller SH. Ecological contexts: furthering resilience, risk and protection factors. Estud Psicol (Campinas) 2008; 25:405-16. 


\section{Resumo}

A reflexão sobre a promoção da saúde para pessoas portadoras de deficiência física envolve a consideração das especificidades e dos sentidos atribuídos à experiência de vida de cada sujeito ao longo da vida. $O$ estudo foi projetado para investigar a experiência de um homem portador de uma deficiência física adquirida devido a uma lesão raquimedular. A lesão resultou na incapacidade permanente de movimentar as pernas. É um estudo de caso que usou a técnica de história de vida para captar a experiência do sujeito. O participante havia nascido na zona rural, e teve que trabalhar desde criança para ajudar a família. Aos 16 anos, começou a trabalhar como operador de motosserra, e aos 24, uma árvore caiu sobre ele, fraturando a coluna vertebral e deixando-o sem movimentos $e$ sensibilidade nas pernas. O trauma vivenciado pelo indivíduo resultou em mudanças profundas na vida dele. Os resultados demonstraram que a experiência deste indivíduo se destaca das experiências tradicionais relatadas na literatura em geral em casos semelhantes, como o conceito de ruptura biográfica. O esporte funcionou como mecanismo vital de colaboração no processo de reabilitação. Quanto à saúde e doença, há muitos espaços na experiência do sujeito que colaboram para ampliar a compressão nos caminhos da promoção da saúde. Foi destacada a necessidade de despatologizar o olhar das condições do sujeito para que a compreensão dos processos de promoção da saúde possa ser ampliada ou repensada.

Pessoas com Deficiência; Acontecimentos que Mudam a Vida; Promoção da Saúde; Pesquisa Qualitativa

\section{Resumen}

El reflejo de la promoción de la salud en personas con discapacidades físicas implica considerar las especificidades y significados atribuidos a la experiencia vital de cada sujeto, a lo largo de su trayectoria. Este estudio se diseñó para investigar la experiencia de un hombre con una discapacidad física adquirida tras un accidente que afectó su columna vertebral. Su lesión le causó una incapacidad permanente en el movimiento de sus piernas. Se trata de un estudio de caso que utilizó una técnica de historia vital para recoger su experiencia. El participante nació en un contexto rural, y desde que era niño tuvo que trabajar para ayudar a su familia. A la edad de 16, empezó a trabajar como operario de motosierra y, con 24 años, la caída de un árbol sobre su espalda le provocó una fractura en su columna vertebral, dejándole sin movimientos y sensibilidad en sus piernas. El trauma vivido por el participante le causó profundos cambios en su vida. Los resultados demostraron que la experiencia del participante no se ajusta a las tradicionales experiencias encontradas en la literatura en general, como el concepto de ruptura biográfica. El deporte fue un mecanismo de vital importancia en la colaboración con su proceso de rehabilitación. Respecto a la salud y la enfermedad, existen muchos espacios en la experiencia del individuo que colaboran para expandir la compresión de las vías de promoción de la salud. La necesidad de despatologización de la percepción sobre las condiciones resaltadas del individuo es necesaria para que, de esta forma, los procesos de promoción de la salud puedan ser reforzados o reconsiderados.

Personas con Discapacidad; Acontecimientos que Cambian la Vida; Promoción de la Salud; Investigación Cualitativa
Submitted on 24/Mar/2020

Final version resubmitted on 11/Jul/2020

Approved on 10/Aug/2020 